\title{
User-led innovations and participation processes: lessons from sustainable energy technologies
}

\author{
Michael Ornetzeder ${ }^{\mathrm{a}, *}$, Harald Rohracher ${ }^{\mathrm{b}}$ \\ ${ }^{a} Z S I$ - Centre for Social Innovation, Linke Wienzeile 246, A-1150 Vienna, Austria \\ ${ }^{\mathrm{b}}$ IFF/IFZ - Inter-University Research Centre for Technology, Work and Culture, Schlögelgasse 2, A-8010 Graz, Austria
}

\begin{abstract}
In this paper we will pose the question whether a higher level of user participation could be used as a strategy to improve the development and dissemination of sustainable energy technologies. We will especially focus on user-led innovation processes with a high involvement of individual end-users.

In our argument we will draw on several case studies in the field of renewable energy technologies - in particular solar collectors and biomass heating systems - and sustainable building technologies. Users in these case studies were involved in the design or planning processes, sometimes in a very selective way and with limited influence, sometimes very active and for quite a long period of time. Especially in the case of renewable energy technologies self-building groups were highly successful and resulted in improved and widely disseminated technologies.

Based on the empirical results of our case studies we will critically discuss the potential of user involvement (especially in selfbuilding groups) for the development and promotion of sustainable energy technologies and outline technological and social preconditions for the success of such approaches.

(C) 2004 Elsevier Ltd. All rights reserved.
\end{abstract}

Keywords: User-led innovations; Sustainable energy technology; Constructive technology assessment

\section{Introduction}

Discussion about the promotion of energy efficiency and renewable energy carriers is usually split into several compartments:

- behavioural changes, focusing on the individual consumer of energy and his/her consumption decisions, attitudes and the practices of using energy consuming devices (using CFLs, switching off devices instead of stand-by mode, etc.);

- technological change, focusing on the development and use of sustainable energy technologies (e.g.

\footnotetext{
${ }^{*}$ Corresponding author. Tel.: + 43-1-4950-442-54; fax: + 43-1-4950442-40.

E-mail addresses: ornetzeder@zsi.at (M. Ornetzeder), rohracher@
} ifz.tu-graz.ac.at (H. Rohracher). energy-efficient washing machines, biomass heating systems);

- institutional change, focusing on regulatory measures, norms, energy taxes, etc. (often addressed as 'social or institutional barriers' also).

In our paper, we will concentrate on a specific way of linking these levels and investigate a number of cases where the collaboration of users of energy technologies has not only contributed to a wider dissemination but also to technological development and product innovation. Users in our case studies have been organised within self-building and planning groups and therefore have been involved not only with behavioural questions but also with technological problems and institutional conditions. Without doubt, self-building is a strategy which will only activate a limited number of prospective users, even if there was an extraordinary diffusion success in the solar case (we will 
discuss later on, which conditions would be favourable to facilitate such an involvement). So, beyond having knockon effects on technology development, such activities should be seen as an additional element in the portfolio of strategies to introduce and improve new sustainable energy technology.

So far successful examples of user-led innovations, i.e. technologies which have even been developed or improved in user groups, have mainly been studied in the area of renewable energy technologies. A famous example is the development of wind turbines in Denmark (see Karnøe, 1996; Jørgensen and Karnøe, 1995) which was strongly influenced by local co-operatives, compared to the more science-based development of wind turbines in the US. In this paper we will complement this example with two more case studies on renewable energy technologies - thermal solar collectors and modern domestic biomass heating systems - which have also been strongly pushed by selfbuilding groups, i.e. prospective users who collectively assemble (and improve) these products. In all of these cases the strong participation of prospective users has given rise to a series of innovations leading to specific design features of these technologies that has been highly functional to a wide dissemination. Moreover, we will discuss a similar case from the construction sector: the collective planning of ecological buildings by prospective users. These examples are instructive partly because of similarities and also due to some differences. In all three cases, prospective users have cooperated in temporary groups, provided with very similar internal social structures, and in all three examples the activities are referring to energy technologies in the household sector. Moreover, the examples cover planned (sustainable buildings) and unplanned (solar collectors) processes as well as examples from different geographical regions.

The interesting questions for us are: Is it possible to transfer the experiences and success stories from the sector of renewable technologies to energy-efficiency technologies? Under which conditions and in which cases could such a direct form of user involvement work? How could a higher participation of users be promoted in certain areas of technology development? Although the question of transferring experiences with self-building from renewables to energy efficiency technologies may be somewhat speculative, we will present some ideas on technologies or applications where such an approach might also work. In particular, we will focus on a hypothetical example for possible user involvement by self-building activitiesthe development and improvement of 'smart home' applications devoted to energy efficiency. Based on this example we will finally discuss some options of selfbuilding as a strategy to support innovation processes in general.
To get the message clear: what we are aiming for is not a plea for an unconditional support of self-building groups as a way to develop and introduce sustainable energy technologies. We rather want to point out that under certain conditions a higher degree of user involvement or self-building groups might lead to a successful mode of innovation which has often been neglected and which could contribute to the design and diffusion of certain energy technologies.

\section{The role of users in innovation processes}

Let us first start with some general remarks on the role of users in innovation processes. Contributions from the field of social studies of technology have emphasised the importance of users in technology development. Users ${ }^{1}$ or future users of technology are seen as an important source of innovation (see e.g. Von Hippel, 1988). In many cases technical improvements are realised during the diffusion phase by user feedback or re-invention by users (see Rogers, 1995). Our case studies of user-led innovations show how the users can be involved in the design and dissemination of technologies at different levels of intensity. Early users can start off completely new technologies and designs (e.g. a specific type of self-built solar collector). They can find and test new applications of a product (such as solar space heating). They can be the source of incremental technical changes (like the control system or additional security components in biomass heating systems) or they can appropriate unconventional building technologies and design solutions in the course of collective planning processes.

However, as the analysis of literature on technological innovation and users reveals, the role of users in innovation processes is much broader than the focus on self-building groups (i.e. user groups who assemble and implement specific technologies on their own, as will be pointed out in the case studies) and direct user participation might suggest. Even without active user engagement, practices of use and images of users shape the design of technologies and products: through the imagination of designers about future uses and users, through the experiences of designers or producers as users $^{2}$, or through various techniques to represent the

${ }^{1}$ It should be mentioned that the term user is rather ambiguous. In innovation studies users are very often firms or organisations (with respect to certain products, they can be producers of other goods). Moreover there is a range of intermediate users, e.g. doctors in hospitals who may be addressed as 'users' of drugs or other products by pharmaceutical companies, although the end-user is the patient. In this paper we mainly refer to individual end-users of energy-efficient technologies in households.

${ }^{2}$ As it turns out it is not so rarely the case that designers of products are at the same time users, sometimes their own first users (see Akrich (1995), or for the case of sustainable buildings Rohracher and Ornetzeder (2002)). 
needs and expectations of future users and match it with the design of a product. Moreover, users actively appropriate products and technologies without being directly involved in the design process: ${ }^{3}$ by using technologies in a specific way or by attaching particular meanings to technologies and integrating them in a 'cultural universe'. Users may also try to change or redesign technologies, or block their usage (as sometimes experienced with ventilation systems in sustainable buildings).

During the design and dissemination of a technology, designers and users are linked to each other through a number of processes and relations:

- both sides refer to certain discourses (e.g. of sustainability, modernity), which at the same time restrain their 'room for manoeuvring' and orient their expectations and actions;

- technologies are part of wider sociotechnical regimes and sociotechnical landscapes (Rip and Kemp, 1998) which also include joint expectations, social practices and institutions (norms) and thus also relate technology design and use;

- intermediate actors (such as energy agencies or consumer associations) translate and mediate between the interests of producers and users.

Seen from this perspective users can be conceptually located within a field of tension-of passively being configured by other actors and of actively appropriating technologies (see Shove, 2003).

Beyond the observation that users in the widest sense always play a role in technological innovations (because products are always culturally appropriated), we also have to ask about the quality of the mediations between design and use. Generally these mediations can be understood as social learning processes between the various actors involved in the development, distribution and adoption of technologies, which may lead to a better match of design features and practices of usage and are crucial for the successful dissemination of technologies. However, these learning processes often happen in a non-systematic and barely reflected way, and in many cases do not make sufficient use of the available potential of user experiences and expectations for further product improvements.

This is the stage where self-building activities, as described in the case studies, enter the picture. User participation may be one tool (under certain conditions) which may help to improve such learning processes. In a way self-building activities are one of the extreme poles of the range of possibilities for user involvement and activities: users develop (or at least assemble) technol-

${ }^{3}$ For a discussion of the appropriation of technologies, see e.g. Lie and Sørensen (1996), or Mackay and Gillespie (1992). ogies on their own. As our cases show, even within these self-building activities, various levels of user involvement can be found. Participation ranges from bottomup initiatives with a largely independent design of technologies and establishment of organisational structures to more top-down oriented approaches, where groups are centrally organised by an existing organisation and products are mainly assembled from prefabricated components. Beyond such do-it-yourself approaches there are also less intensive ways of user participation, such as 'stakeholder workshops' in the early phase of product design (as suggested by the approach of Constructive Technology Assessment, e.g. Schot, 2001), or the selection of a small number of interested and innovation-oriented users to jointly improve product specifications, as attempted in the lead-user method (e.g. Herstatt and Von Hippel, 1992).

\section{Successful examples of user-led innovations: three case studies}

In this section, we will set out to study some examples of the collective self-building of technologies and participative planning processes, as a possible way to develop more appropriate technologies and enhance dissemination. The first two cases are renewable energy technologies, while the third one is an example from the planning of green buildings. In light of the characteristics of such examples, we will make some (limited) generalisations in the following section and ask for preconditions of a higher user participation in technology development and the chances to transfer such results to the area of energy efficiency.

\subsection{Thermal solar collectors}

In Europe, solar water heaters were not adopted until the 1973 OPEC oil embargo. From 1973 to 1978, the development of solar technology was influenced mainly by research activities and funds from public institutions and industrial companies. A first slight boom took place on the Austrian market for solar water heaters from 1979 to 1981 , mainly caused by the second oil crisis, increasing private demand and the market penetration by large-scale companies. This boom came to a sudden end in the early 1980s, due to the stabilisation of the oil price, and problems with the technical reliability of installed systems. However in 1987, a second boom started and it is still active. In the second half of the 1990 s more than $150,000 \mathrm{~m}^{2}$ collector surface per year was installed in Austria (Faninger, 2000). Due to this mature domestic market, Austria's solar industry was able to take a pioneering role in Europe. Today the export share of solar collectors exceeds the domestic share. According to a recently published report, Austria 
leads the European per capita solar statistics with an installed collector area of approximately $290 \mathrm{~m}^{2}$ per 1000 inhabitants by the end of 2001 (Fink, 2002). Also considering the annual growth rates, Austria is situated in the first position, with Greece, Denmark, Switzerland, and Germany following (Stryi-Hipp, 2000). By the end of 2001 , more than $1.700000 \mathrm{~m}^{2}$ of flat plate collector surface were installed in Austria. At present, approximately $15 \%$ of all private single-family houses are producing hot water by means of solar heaters (Faninger, 2000). Interestingly, this extremely successful dissemination rate is partly due to the fact that more than $400,000 \mathrm{~m}^{2}$ collector surfaces were manufactured in privately organised do-it-yourself groups (Fink, 2002). Approximately, 40,000 solar heaters are equipped with self-built collectors in Austria.

The user initiative which set off this development first, started in the early 1980s, even at a time when the topic of solar energy was no longer in the focus of the public debate. Two skilled Styrian amateur inventors, a fruit farmer and a technical engineer, were fascinated with thermal solar technology. Together with some friends, they developed a simple self-build method adapted to the needs and abilities of the rural population aside from the commercial market for solar heaters. The first selfbuild group with 32 participants was established in a small village near the city of Graz in 1983 . The idea to practice do-it-yourself methods in groups and not individually was mainly based on a local tradition. This rural part of Austria, Eastern Styria, is well-known for its wine and fruits. People of this countryside are used to cooperating at least during harvest season. Even in a technical world, apples of high quality have to be picked manually. Thus, once a year, all available family members, friends and neighbours work together for a short time. Thus, if one were to know how to organise and motivate an informal working group it would be easy to transfer this social pattern of cooperation to other purposes.

The positive experiences of constructing solar collectors in self-building groups of prospective users of these collectors were soon spread by word of mouth and fuelled neighbouring communities' interest to start similar groups that tapped the sun's energy. Before the end of 1984, the enormous local demand for solar collectors required the establishment of two more selfbuilding groups, each with more than 100 participants. When more requests were made from other parts of eastern Styria, some of the more active knowhow carriers decided to hold a series of evening lectures in order to report on the solar system self-build method.

In 1986 and in the following years, the Styrian selfbuilders based only in a small region were able to produce more solar collector surface area than all commercial suppliers in Austria put together (see Fig. 1). In order to meet the ever increasing demand in 1987, the first solar system build-it-yourself guide was produced. Training seminars were organised for construction group leaders and other interested persons who wanted to familiarise themselves with the method of solar system self-building. To improve communication, a news bulletin titled 'solar info' was established. An important step in this process was the institutionalisation of the self-build movement. The Association for Renewable Energy (AEE) was founded in June 1988. The AEE was awarded several environmental and research prizes, which brought them additional recognition. As an official representative of the solar system self-build movement, the AEE was able to receive public funds support. This enabled the AEE to do their work on both a broader and more stable basis. After a few years, the AEE expanded throughout Austria by establishing regional divisions. The self-build method also found followers in neighbouring countries such as Switzerland, the Czech and Slovak Republics, and Slovenia. The AEE became, meanwhile, one of the most important know-how carriers not only in the field of thermal solar energy but also in regard to other renewables in Austria. For the sixth time in the year 2002, the AEE has organised an international symposium on thermal and photovoltaic use of solar energy.

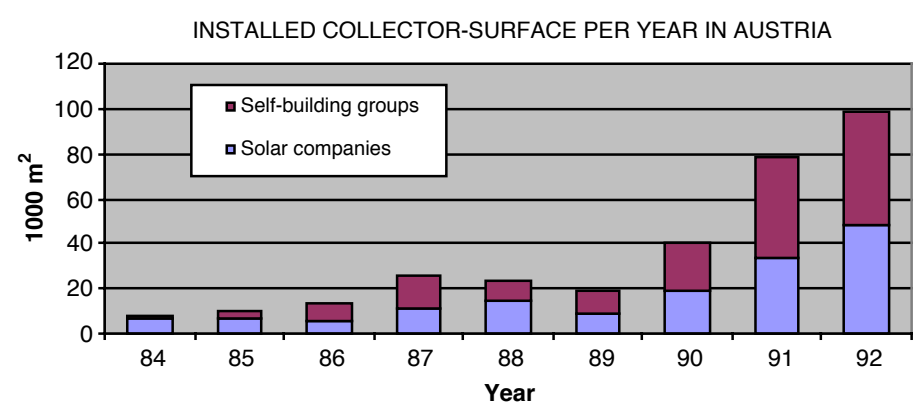

Fig. 1. Market share of self-building groups and companies in Austria. Annually installed collector-surface from 1984 to 1992. 
The AEE's latest step toward professionalisation was the establishment of a planning office in 1993.

The production of self-built solar systems was mainly organised in autonomous groups with participants between 10 and 100 . The foundation of a new group started, in most cases, with an introductory lecture and an excursion to existing self-built solar systems. Former group leaders or members of the AEE then offered individual technical advice and guided the work within the new group. These activities were of prime importance for the second boom on the Austrian solar market at the end of the 1980s. In detail the main steps of the applied strategy could be described as follows:

1. Introductory lectures: First, independent community lectures concerning the use of solar energy and the methods of self-building are presented. The organisation of these lectures occurs mainly through resident people interested in solar systems. By using local organisations to arrange the lectures, the scepticism toward the unknown is largely reduced, resulting in more interest. These lectures bring the subject 'renewable energy' to the people and present them with a possibility for action. For more than half of the self-builders, such a lecture is the first contact with the topic of renewables.

2. Visits to installations: If people are interested in building their own solar system, they are usually invited to both join an excursion to one of the existing self-built solar systems and to talk to the users about their experiences. The possibility to prove the performance of this technology is a crucial point within the whole decision process. Specifically, it helps to reduce uncertainty about this technological innovation.

3. Sizing the system: In the course of a further meeting, a member of the AEE calculates the size of the system, explains the connections to the existing heating and hot water system and gives advice about optimal integration. This service is necessary due to the uniqueness of every household. The calculation also helps to reduce existing uncertainties about the compatibility of solar systems.

4. Formation of self-building groups: If participants agree to form a self-build group, a few people become responsible for the coordination and organisation of their group. These group leaders are provided with technical and organisational know-how at weekend seminars offered by the AEE. Every self-build group is a financially independent organisation, which decides alone where the necessary materials should be purchased. This collective purchasing enables very low prices.

5. Construction phase: The absorbers are manufactured collectively. The necessary tools such as presses, bending and soldering jigs are made available to the groups by the AEE. Teamwork also enables people with less technical experience to take part. Only after all the necessary absorbers have been produced, they are distributed among the group members.

6. Dissolution of the groups: The average life of such a construction group is approximately three to four months. While the assembly and installation work is either done by the group members themselves or with the assistance of local installers, it is recommended by the AEE that groups should arrange for 'neighbourhood teams' already during the construction stage in order to facilitate installation by the group.

In addition to the enormous dissemination success of this strategy, the activities in a large number of selfbuilding groups led to some important technical optimisations stimulated by user experiences and user feedback. From 1986 onwards, the self-build group leaders met on a monthly basis to discuss the advantages and drawbacks of different types of systems. During that period, the technical system underwent a number of important improvements based upon practical feedback of former participants and technical skills of new group members. For instance, the piping of the absorber was no longer soldered at every bend but produced from a single piece of copper tube. For this purpose, a special tube-fitting table was developed. At the same time, the device used for soldering sheets and piping was considerably improved. Over the years these special tools developed into a complete 'tool kit' that was rented to new groups against payment of a small fee. These technical innovations brought about not only manufacturing advantages but, by making soldering spots redundant, also a reduction to the finished system's susceptibility to break down. A further improvement was achieved with regard to the collector housing, which for anti-corrosion purposes was no longer made of zinc-lined steel sheet but of high-grade steel. As in 1986, the first collectors that could be directly integrated into the house roof-provided that the tilt and orientation were suitable- became available. This installation method - at that time exclusively used by self-builders - made it possible to cut financial expenses by avoiding the need for steel housing and, in many cases, it provided an aesthetic solution which encouraged the dissemination of solar systems considerably.

In the mid-1980s, users of self-built solar systems began to use existing hot water systems for spaceheating also. Because of a lack of commercial examples, those activities were rather innovative. Most of the experiments started quite simple. Some of the self-built solar systems produced more heat than the households were able to consume, so some users adapted the existing systems in order to heat the bathroom (a room where higher temperatures are welcomed even in 
warmer seasons). Based on these first experienceswhich were quite encouraging - space-heating became an intensively discussed issue in the group leaders meetings. Shortly after these discussions, the first hot water and space-heating designed systems were realised in some self-built groups. Starting from very limited heating capacities, the self-builders have developed an economically optimised type of solar combisystem working as an ecological backup of the existing heating system. Solar heating with such combisystems was also very important for the dissemination success of solar systems in general. Today, approximately, every second new installed solar system in Austria is realised as such a combisystem.

In this respect, the self-build movement could also be seen as a large decentralised 'development division' for solar heating systems, in which over many years a great number of practice-relevant technical improvements and new forms of applications were compiled and realised. A great number of users all over Austria were and still are in contact with the AEE. Within this network of qualified users, positive and negative experiences with the technology are communicated. As a result of selfbuilding these users are very 'close' to the technology and some of them have been directly involved in the improvement of the technical system. As historical studies of technology show, such a dispersed development and collective improvement of technologies can especially be found in early phases of product development - an example is early user clubs in the development of the personal computer.

Many of these improvements have been adopted by commercial producers and installation companies (e.g. a special glass cover sealing, using parts of available glasshouse systems; roof-integrated collectors; solar systems for space heating), which currently operate as very professional and successful enterprises. In Austria, commercial solar systems are of good quality and prices are much lower than ten years ago. Contrary to the misgivings of solar companies, the success of the self-build movement had positive effects on their sales as well. The further development of the solar market had an increasing dynamic by a "selfenforcing process". A growing number of solar collectors made it easier for potential adopters to visit existing devices. More information about this new technology was spread. It was more likely to have a friend or acquaintance who already had a solar heating system. In recent years solar companies have been extremely successful in Austria, partly because of this specific precondition.

\subsection{Biomass heating systems}

The second case we want to turn to are domestic biomass heating systems. In 1998 biomass contributed with $125 \mathrm{PJ}$ or $10.5 \%$ to the total primary energy use in Austria. Accounting for more than $57 \%$ of the biomass used for energy purposes, fuel wood is the main source of biofuel in Austria. Fuel wood still is an important energy carrier for domestic heating in rural areas (between a third and a fifth of all households), due to the high proportion of forests in Austria. However, although these figures seem quite impressive (and are among the highest proportions of bioenergy in Europe), they conceal a lot of problems for the future development of renewables in domestic heating. As mentioned above, much of the high proportion of renewables in Austria is due to the use of wood-a traditional energy carrier that rather is on the decline and not a signifier of a new move to renewables. The main strategy chosen to sustain the high level of fuel wood use has been to develop new heating systems. ${ }^{4}$ Major steps have been made in the past 15 or 20 years to improve the technological standard of domestic heating with biomass. Today domestic biomass heating systems have hardly anything in common with traditional woodstoves, which are still widespread in Austria. Modern biomass boilers are used as central heating systems and are highly specialised in certain kinds of woodfuel. The main types are woodchip boilers, which operate (fully) automatically over the whole heating season, but meanwhile boilers for pellets (pressed from saw dust) are growing in importance, especially outside the agricultural sector.

In the period of the early development of modern biomass boilers, self-building groups have been organised between 1985 and 1989 by two organisations: the Association for Regional Development (OAR) and the Chamber of Agriculture. Compared to solar collectors, the self-building activities were more centrally organised. One motivation was that activists who had been engaged in building solar collectors were looking for additional opportunities to develop and install sustainable technologies. Together with OAR they developed a technical concept for woodchip boilers, which were commercially available at that time but of rather bad quality and low efficiency. As the organisers of these groups pointed out in articles, the advantages of such self-building groups were:

- the jointly organised purchase of materials and mechanical components;

- lower prices because of large quantities of components;

- low-cost production due to DIY (price-cuts could range from $25 \%$ to $50 \%$ );

- mutual support in group work;

${ }^{4}$ For an analysis of the development and introduction of this technology from a sociotechnical perspective, see Rohracher (2002b). 
- high reliability of heating system because of well-tried design;

- everybody knew his/her system and would be able to repair it;

- experience of collective work and support.

All in all, between 10 and 15 such groups with 10-12 participants each were established. This does not sound an awful lot, but given that at that time about 170 boilers were purchased in Styria (1.2 million inhabitants), an additional number of 12 new boilers in a village were quite significant and newsworthy. We will not look in detail at the organisation of the groups but focus on some technical changes which came out of these activities.

Two main, rather incremental, technical changes first appeared in self-built biomass boilers before they became a standard feature of commercial boilers (though there is no hard evidence that the commercial sector adopted these ideas and did not develop it independently). The one change was a much more advanced safety system to prevent an inflammation of the stored woodchips through 'back burning' from the combustion chamber. Safety was a prominent and permanent topic in the discussions of the self-building groups and everyone wished to have the highest possible protection. Downspouts and fire sprinklers were installed between storage and the boiler and photosensors controlled sensitive places to prevent back-burning. The second innovation was an electronic control system, which was much smaller, more flexible, 'intelligent' and comfortable than the electro-mechanic systems that existed at that time. Not only were the safety devices integrated in the control system, but the user interface also allowed to set temperatures in advance etc. The two areas of innovation thus were safety and comfort - two issues that are high on the agenda of users but apparently were not sufficiently taken into account by early boiler manufacturers.

However, as it also turned out, the construction type of self-built boilers (which was one of two main types of construction available at that time), which was primarily determined by the wish to be able to easily integrate these boilers into existing systems (and even using parts of the existing boiler) turned out to be a technical deadend for a number of reasons. The design that finally was adopted by commercial producers was much more difficult to produce in self-building groups. ${ }^{5}$ Although participants were highly content with their work in the groups and the product they produced, self-building was

\footnotetext{
${ }^{5}$ One possible way out of this problem, as one of the group organisers suggested, would have been to increase the degree of prefabrication (in collaboration with a producer company) and mainly assemble the boiler.
}

stopped because OAR did not get further finance for their co-ordination and organisational work and because organisers had the feeling that commercial boilers were of sufficient quality meanwhile.

\subsection{Sustainable buildings}

In contrast to the technology-centred case studies on solar collectors and biomass heating systems, the third case study is from the field of sustainable buildings. The focus in this example is more on collective planning of ecological buildings, but due to very similar organisational structures a comparison offers some additional insights in participative design and planning processes. The case study concentrates on co-building groups in the German city of Freiburg which have been active in the development of a new sustainable residential area (Sperling, 1999).

In the South of Freiburg, on the former area of a French barracks site, the new 'Vauban' residential area is being developed for 5000 inhabitants. The planning process started in 1993 and in 2006, after three development sections, the district will be completed. In spring 1995, the City of Freiburg initiated a process of citizen participation, based on the experiences in another development project, the 'Rieselfeld'. Because of unsatisfying results of this first participation process the private association Forum Vauban e.V. was established and was accepted by the city to be the organising body of the participatory process in Vauban. The city gave some core funding to Forum Vauban which enabled it to establish citizen participation on a professional basis.

From the very beginning, Forum Vauban did not want to restrict itself to merely organising and coordinating, but developed suggestions for the planning of the district. Therefore, Forum Vauban got additional funding of the German Environmental Foundation. Experts developed a set of measures for a 'sustainable model city district Vauban', dealing with the fields of traffic, building, energy, nature in the city, sanitation and public space. The results of this study were discussed with citizens and finally presented to representatives of the city. Many of these suggestions became part of the official planning objectives, others were implemented later on by private initiative in parts of Vauban.

Another issue at that time was to get in contact with future inhabitants of Vauban. For that purpose, Forum Vauban and the city council jointly ran a publicity campaign with special regard to ecological and social city planning in 1996. After this campaign, Forum Vauban organised information fairs and encouraged interested people to form co-building groups.

Key dates of the sustainable model city district Vauban (Forum Vauban, 2002): 
1993 start of the project on December 14th

1995 start of the participation process: Forum Vauban e.V. is recognised as legal body of the extended participation process and is funded by the city

1996 main discussions about the master plan, Forum Vauban influences the planning based on the results of research project and discussions with citizens, large publicity campaign mobilising the first future inhabitants, formation of the first cobuilding groups, Freiburg-Vauban is a German Best Practice at the Habitat II conference in Istanbul, bimonthly district newspaper 'Vauban actuel'

1997 concepts are taking shape: EU-LIFEproject supports the implementation of sustainability concepts in the fields of mobility, energy and social/ecological building, the first building lots become available for co-building groups, cooperative building initiatives, private builders and a limited number of commercial builders

1998 start of construction (1. phase), 140 out of 450 units are organised in co-building groups

2000 'turning point' of the Forum's work: completion of the EU-LIFE-project, conceptual and scientific work is completed and documented, the new focus is on social work (communication with all new inhabitants and the development of neighbourhoods)

2001 start of the second construction phase, 30 co-building groups with around 300 participants

2002 many people move into the second sector, start of the neighbourhood centre, more than 2700 people are living in Vauban

2006 official end of the project by December 31 st, all building lots will be sold and the residential area will be completed

The organisational structure of the above mentioned co-building groups is of special importance for our discussion. Forum Vauban favoured this form of building from the beginning because it promised the best combination of both participation and individual planning on the one hand and the realisation of the ambitious aims of the sustainable model city on the other hand.

Co-building means that future inhabitants organise themselves within groups of 5-15 families in order to plan and build a house together. In most cases, these groups were formed around existing social relations, starting with similar visions for the new house and looking for additional group members. Having reached the appropriate size the group is bound together by contracts, acquires a building ground, assigns an architect, plans the building in cooperation with the architect and other planners, and finally commissions a construction company to realise the project.

Co-building in that form is not so rare in the field of ecological housing (Gestring et al., 1997). However, in Vauban the different groups were integrated in a network by a special coordination structure and the Forum Vauban provided consulting services throughout the whole process. Representatives of each group met on a monthly basis to discuss technical questions, share their experiences and problems, and to support each other. These meetings - organised by Forum Vauban staff members - made not only the coordination between the different groups possible but also allowed to prepare information material important for all groups. In different stages of the planning process Forum Vauban organised information fairs, individual consultations, or excursions to existing eco-villages. Moreover, Forum Vauban was able to influence the individual planning, in order to meet the ecological requirements, and to represent all co-building groups in negotiations with the city or construction companies.

Within the first and second construction phase 45 cobuilding groups were formed with around 450 members (families). That means that nearly one-third of all flats in Vauban were realised by co-building groups. Within these groups, the future inhabitants were able to build individually but also very cost-effective. Moreover, the new neighbourhoods began to grow at a very early stage. Many co-building groups have realised themselves special ecological and social measures within their new homes beyond the official planning which already includes for example low energy building, public transport and keeping cars outside the district. Most individuals were intensely involved in the planning process which resulted in high identification with most of the technological decisions. Therefore, the special type of co-building in Vauban provided an unusual basis for technical innovation. Most of the co-building groups were encouraged by this structure to realize very innovative building concepts with new and unusual technologies (e.g. vacuum toilets in combination with a collective biogas system). The user experiences with such technologies will be very important for the further development and dissemination. 


\section{User participation and energy-efficient technologies}

\subsection{Lessons from the case studies}

Our case studies highlight the role of users in innovation processes under specific social conditions. As we could see, most users were involved in cooperative production or planning processes. As a result of selfbuilding and planning in groups, these users started to modify and improve the technology, and sometimes even completely new technical options came up. Selfbuilding groups accelerated the dissemination, participative planning promoted the adoption of novel and sometimes risky technology. All forms of participation are linked with social learning processes. In detail the reported examples resulted in several positive effects such as:

- Technical innovations: Within solar and biomass selfbuilt groups a wide range of technical innovations and incremental improvements have been developed (e.g. special type of self-built collector, roof-integrated collector, solar combisystem for space-heating, electronic control system and advanced safety system for biomass heaters). Some of these innovations have been adopted by commercial producers and installation companies later on.

- Dissemination of technology: Especially in the case of solar collectors self-built groups have stimulated the diffusion of the technology considerably. In Austria approximately 40,000 households are equipped with self-built solar collectors. Reasons for this successful dissemination are low-investment costs due to bulk purchases and personal contribution, personal advertising by company-neutral users (lectures and excursions), social motives to join a group in the neighbourhood, relative advantages of solar systems in rural regions (added comfort).

- Social embedding of unconventional sustainable technology: Users organised in co-building groups deliberately decided to adopt very innovative and partly risky technologies (e.g. vacuum toilets in combination with biogas systems in the city district Vauban) and to realise novel building-concepts (e.g. ecologically optimised passive houses). The resulting user experiences with those technologies are of major importance for further technical improvements.

How can we explain this success? Of course, there are many reasons and most of them have been already discussed in the examples. But from a more general perspective, a specific form of social organisation seems to be particularly important in this respect: autonomous social groups embedded in a wider social network and linked together by a coordinating structure.

In all case studies, users are organised within temporary social groups aiming at a common purpose.
People with different professional backgrounds, skills, and different experiences come together and share these abilities. In contrast to individualised forms of DIY, people in our cases organise groups in order to benefit from each other. The cooperation is mainly based on mutual trust, therefore it is helpful to form groups around existing social relations. Trust also ensures that innovation-relevant information is freely disclosed and assistance is given for free. As we know from small group research, the effectiveness of groups regarding specific tasks (like searching, defining, or judging) is much higher compared to the individual performance of all group members (Hofstätter, 1986). Interaction and mutual completion in groups are primarily responsible for that effect. In many cases groups therefore help to avoid shortcomings. These general characteristics of small groups are effective in the studied examples as well. The temporary technology-centred group creates a stimulating learning space and is a potential source of technical innovation.

In spite of these positive effects of group organization, the influence of single self-built groups on the technical development would have been very limited without a more stable coordinating structure. In the solar case such a structure was developed by some active group leaders (later on institutionalised as an association), in the biomass case and in Freiburg-Vauban existing organisations took over this networking activity. The coordinating structure is able to organise the communication between different user groups and links the activities to a wider network of relevant social actors, such as manufacturers, suppliers, professional planners, funding agencies, etc. Such a stable organisational unit enables long-term learning processes between different user groups and between users and professional producers. It is possible to collect all the different ideas and experiences from several groups, to assess and select them, and make them available to new building groups and other interested social actors.

Our investigation of self-building (and planning) groups for renewable energy technologies also gave some evidence of a number of preconditions and success factors of technology development with high user participation. The following paragraphs give a preliminary list of supposed restrictions and conditions for such a mode of product development:

- Technical characteristics: Even the differences between the self-building experiences of solar collectors and biomass boilers reveal that technical characteristics may have a strong influence on the chances of such a kind of user involvement. Technologies appear to be appropriate for self-building, if they are technically not too complex (e.g. the present construction of biomass boilers appeared not to be feasible for self-building) and if they do not need highly specialised and expensive tools to fabricate, or 
if a high level of technical competence is required. However, there are ways of dealing with such a situation, like increasing the degree of pre-fabrication of components and closer collaboration with producer companies.

- Lifecycle of the products: Apparently the chances of successful self-building are much higher in the early phases of technology development and dissemination. At this stage it is easier to develop solutions which are superior to (often immature) commercial products. Moreover, potential cost benefits of self-building are higher as long as commercial products are sold in low numbers and cannot sufficiently profit from scale benefits. As soon as cheaper and technically more mature products are offered in the market, selfbuilding activities are often on the decline (e.g. in both of our cases, solar and biomass).

- Specific motivation of users: A specific and high motivation of users is needed to invest sufficient amounts of time and energy into the work of selfbuilding groups. Beside cost reductions (which are an important driver, indeed), issues like 'environmental protection', 'regional development', 'energy saving' or 'using ecological and healthy materials' played an important role. In this way, work in a self-building group can be linked to a mission and can be tied up with broader social aims. Especially organisers and coordinators of such groups, who do not profit from building a second heating system, need such a kind of orientation and legitimisation. A specific case of motivation are hobbies, where self-building is not uncommon (e.g. building boats or gliders from prefabricated parts or with support of manuals).

- Specific socio-cultural milieu: An interesting point is the probable dependence of self-building activities of certain socio-cultural contexts. In the case of solar collectors and biomass boilers, the rural setting already had a tradition of neighbourly help or of jointly using and purchasing expensive tools and machinery in the agricultural sector. In regions and environments, where such traditions do not exist (and this was even the case in smaller cities in these regions), self-building activities appear to have less chances of success. However, the example of Freiburg-Vauban shows that under certain conditions self-organised planning of green buildings may also be successful in cities.

Moreover, such drivers and conditions are traded off with other investments (e.g. time budget needed) and alternative possibilities (e.g. purchasing a modern gas boiler instead of biomass heating) and their performance, price, etc. In our cases, the above-mentioned conditions were either satisfied or participants were restricted to small groups, for whom the self-built product was especially attractive (e.g. for farmers with small forests and own wood residues).

As we can conclude from these case studies, strong forms of user involvement, like self-building of technologies, indeed depend on a number of preconditions. Hence, we must ask: Could such a mode of innovation and dissemination also work for energy-efficiency technologies or a larger number of sustainable energy technologies in general? Or does it only work in a very limited number of cases mainly with renewable energy generation? A number of examples from other technological fields at least support the case that cooperative forms of self-building are quite common. In some prominent cases users did even play a decisive role in early phases of the technical development. Technologies like the personal computer (Allerbeck and Hoag, 1989), open-source software (Von Hippel, 2001a), or sportsrelated consumer products (Franke and Shah, 2003) have been mainly developed by users participating in community-based networks.

Thus, there are good reasons to believe that selfbuilding as an innovation strategy could well be extended to other technologies, for instance to the area of 'energy saving', which at least provides a specific motivation. As the example of Freiburg-Vauban shows, such experiments can work for planning processes of sustainable buildings and the widespread tradition (at least in some countries) of taking part in the building of ones own (usually single-family) house and DIY indicates that energy-efficient construction certainly may be an issue for prospective users of buildings. As we have mentioned earlier, self-building of products is at the extreme end of user involvement and successful participation of users could also work in 'weaker' variations. To get a more concrete picture of such possibilities we will shortly sketch a hypothetical example of a technology related to energy efficiency where more participation of users might help to improve certain applications and support their dissemination: smart home applications to improve energy efficiency.

\subsection{Hypothetical example: smart home technologies for energy efficiency}

Let us give a very rough introduction to this set of technologies. The main characteristic of 'smart homes' is a communication infrastructure, which connects various sensors, appliances, and devices (lighting, heating and ventilation, security systems, household appliances) within the building and often to external networks such as the Internet. Currently, there is a strong push towards these technologies coming from producers and also from building societies, developers, etc. One of the standard arguments for the use and promotion of these technologies is their contribution to energy and, generally, resource efficiency. 
Indeed there are a number of applications which could contribute to sustainability in buildings:

- energy management, i.e. better control and integration of domestic service facilities, such as switching off ventilation and heating when windows are open; separate and programmable temperature control for all rooms; central switch for all power consumers when leaving the house;

- feedback on energy consumption of the building or certain appliances via the Internet;

- load management and other new services provided by, e.g. utilities via power lines;

- intranet solutions in blocks of flats to provide services such as car sharing.

However, given the broad field of possible applications of smart home technologies (e.g. as security devices, for entertainment or convenience), people will not necessarily make use of the resource saving potentials of IT in buildings, but may on the contrary even contribute to additional electricity consumption through further electrification of households and higher standby energy losses. The environmental effectiveness of such technologies thus depends on the practices that develop around it in the course of dissemination and the way the technology is adapted to these new requirements.

In-depth interviews with early users of smart homes in Austria ${ }^{6}$ indeed revealed some similar preconditions than the ones enumerated above for self-building groups. Especially those users of smart home technologies who had a large number of specific applications were especially motivated to improve certain applications, find even new ones and tinker with this technology. Among intensive smart home users, a majority of respondents had a technical vocational background on their own (as electricians or in the IT sector) and interestingly placed considerable emphasis on energy issues. Some of them even had figured out sophisticated control algorithms on their own-e.g. a warm water circulation pump (to immediately get warm water even if the central water heater is at some distance) connected to an occupancy sensor in the bathroom. The pump then only worked for two minutes and the sensor did not react again for the next fifty minutes since the user had discovered that the water stayed warm in the pipes for this time. At the same time, many of these users complained that smart home technologies would increase their dependence on electricians - they were not even able to install a new lamp on their own or change settings of the system without special knowledge.

It is certainly a speculation whether certain kinds of user involvement could be successful for such a technology, but there are a number of points of

\footnotetext{
${ }^{6}$ For more details see Rohracher (2002a).
}

departure to organise activities such as user clubs to develop applications, which are more apt for users than the ones offered presently (which are seen as rather useless by many potential users). On the one hand, user activities, like the one example on circulation pumps, could be supported or organised by, e.g. energy efficiency organisations. On the other hand producers of smart home technologies could develop tools (and some efforts are being made in this direction) which would allow a deeper engagement in designing one's own applications. The interesting question certainly would be whether it is possible to organise and link such user experiences in a way that social learning processes are possible and these activities are also oriented towards broader aims such as energy efficiency.

\section{Methods to promote user-involvement}

Our example on smart home technology should illustrate that there are realistic applications for selfbuilding activities related to energy efficiency. Of course, we have no guarantee that organised self-building would really work in that specific case, but there are some strong arguments which suggest to implement such a strategy to support the development of energy-efficient technologies by direct user feedback. Moreover, organised self-building could be useful for innovation processes in general. Taken into account that classical forms of DIY are very popular in the field of end-user technology we could assume a considerable theoretical potential for self-building groups.

As we discussed earlier in this paper, organised selfbuilding is transferable to other technologies and social contexts under specific conditions. Therefore it is very important that a specific technology is in an early phase of development and dissemination. In this phase there is a higher chance that users come up with new or superior technical solutions. Because of high production costs during the early phase of product dissemination, selfbuilding in many cases is economically attractive, too. The technology itself should provide some space for DIY activities. Specific tasks should not be too complex and feasible without the need for specialised tools and high levels of technical competence. In order to extend self-building to more complex technology, professional manufacturers could provide special user toolkits which allow to transfer more design capability to users (for similar suggestions for non-energy technologies see e.g. Von Hippel, 2001b).

In order to implement self-building as an additional innovation strategy it could be helpful to build on new approaches in the field of technology assessment (TA), in particular 'Constructive Technology Assessment' (Schot, 2001) and 'innovation-oriented TA' (Bröchler and Simonis, 1998), which have been developed in recent 
years. Such approaches no longer concentrate on the evaluation of new technologies, but rather focus on the processes by which technologies arise and, beyond this, attribute a significant role to the potential users of such technologies. Broadening the design process in such a way means that possible problems in the contexts of 'real-world use' can be recognised at an earlier stage and can be minimised by making appropriate changes. Technology assessment thus becomes an increasingly participatory process, systematically nurtured not only by scientific know-how but also by the everyday experiences of technology users.

Applying such an approach to the development of sustainable energy technologies would mean that research institutes and producers have to agree to establish an institutionalised know-how exchange with experienced users. Producers should provide latest technology and/or special construction kits to a selected group of users. The whole participation process could be organised by existing TA-institutes or similar organisations. In order to start up stable learning processes it is of crucial importance to find social niches with highly motivated users, to organise communication among them, and to link user experiences to producers and research units. Experienced users will be interested to contribute in such processes only if they profit personally from the involvement, e.g. by cost reductions or free technical support, and if they are motivated by specific goals associated with the technology, e.g. energy saving. Smart home technology is insofar a relevant example as the products available on the market are in an early stage of development and dissemination and the investment costs are relatively high. There is certainly a potential for energy saving in the household using smart technologies but realistic applications are still missing. As our hypothetical example shows, users are able to come up with such realistic forms of use mainly because they are directly confronted with specific problems and technical conditions.

In any case, the success of planned user involvement will be essentially supported by a social structure consisting of autonomous self-building groups which are connected to similar groups and other relevant institutions within a wider social network. If selected users are addressed not only as users of a specific technology but also as producers or planners (even if this part is rather small), behavioural, technical, and institutional aspects of energy consumption will be integrated and new ways of thinking about new technological options could arise.

\section{Acknowledgements}

We are grateful to the 'Jubiläumsfonds der Österreichischen Nationalbank' for funding our research in participatory technology development of renewable energy technologies.

\section{References}

Akrich, M., 1995. User representations: practices, methods and sociology. In: Rip, A., Misa, T.J., Schot, J. (Eds.)., Managing Technology in Society: The Approach of Constructive Technology Assessment. Pinter, London.

Allerbeck, K., Hoag, W., 1989. Utopia is around the corner: computerdiffusion in den USA als soziale bewegung. Zeitschrift für Soziologie 18 (1), 35-53.

Bröchler, S., Simonis, G., 1998. Konturen des Konzepts einer innovationsorientierten Technikfolgenabschätzung und Technikgestaltung. TA-Datenbnk-Nachrichten 7 (1), 31-40.

Faninger, G., 2000. Der Solarmarkt in Österreich 2000 (Kurzfassung) Klagenfurt/Wien, Bundesverband Solar in der Wirtschaftskammer Österreich.

Fink, C., 2002. Eine Analyse des österreichischen Solarmarktes innerhalb des ALTENER Projektes Soltherm Europe Initiative. AEEE INTEC, Gleisdorf.

Forum Vauban : Geschichte-Überblick [Web Page]. (Accessed 12. Nov. 2002). Available at: 〈http://www.forum-vauban.de/geschichte. shtml $>$.

Franke, N., Shah, S., 2003. How communities support innovative activities: an exploration of assistance and sharing among endusers. Research Policy 32, 157-178.

Gestring, N., Heine, H., Mautz, R., Mayer, H.-N., Siebel, W., 1997. Ökologie und urbane Lebensweise. Braunschweig, Vieweg.

Herstatt, C., Von Hippel, E., 1992. Developing new 'product' concepts via the lead user method: a case study in a "low-tech" field. Journal of Product Innovation Management 9, 213-221.

Hofstätter, P.R., 1986. Gruppendynamik. Rowohlt, Hamburg.

Jørgensen, U., Karnøe, P., 1995. The Danish wind-turbine story: technical solutions to political visions? In: Rip, A., Misa, T.J., Schot, J. (Eds.)., Managing Technology in Society: The Approach of Constructive Technology Assessment. Pinter, London.

Karnøe, P., 1996. The social process of competence building. International Journal of Technology Management 11 (7/8), $770-789$.

Lie, M., Sørensen, K.H., 1996. Making Technology our Own? Domesticating Technology into Everyday Life. Scandinavian University Press, Oslo.

Mackay, H., Gillespie, G., 1992. Extending the social shaping of technology approach: ideology and appropriation. Social Studies of Science 22, 685-716.

Rip, A., Kemp, R., 1998. Technological change. In: Rayner, S., Malone, E.L. (Eds.)., Human Choice and Climate Change: Resources and Technology, vol. 2. Batelle Press, Columbus, OH.

Rogers, E.M., 1995. Diffusion of Innovations. The Free Press, New York.

Rohracher, H., 2002a. Smart houses and energy efficiency. constructive technology assessment of ict use in sustainable buildings. In: Proceedings of the 2002 ACEEE Summer Study on Energy Efficiency in Buildings: Teaming for Efficiency. American Council for an Energy-Efficient Economy, Washington, DC.

Rohracher, H., 2002b. A sociotechnical mapping of domestic biomass heating systems in Austria. Bulletin of Science, Technology \& Society 22 (6), 474-483.

Rohracher, H., Ornetzeder, M., 2002. Green buildings in context: improving social learning processes between users and producers. Built Environment 28 (1), 73-84.

Schot, J., 2001. Towards new forms of participatory technology development. Technology Analysis \& Strategic Management 13 (1), 39-52. 
Shove, E., 2003. Users, technologies and expectations of comfort, cleanliness and convenience. Innovation 16 (2), 193-206.

Sperling, C., 1999. Nachhaltige Stadtentwicklung beginnt im Quartier. Ein Praxis- und Ideenhandbuch für Stadtplaner, Baugemeinschaften, Bürgerinitiativen am Beispiel des sozial-ökologischen Modellstadtteils Freiburg-Vauban. Öko-Institut, Freiburg.

Stryi-Hipp, G., 2000. The European Solar Thermal Market. In: Arbeitsgemeinschaft Erneuerbare Energie (Ed.)., Proceedings der
Tagung Gleisdorf Solar 2000. Arbeitsgemeinschaft Erneuerbare Energie, Gleisdorf

Von Hippel, E., 1988. The Sources of Innovation. Oxford University Press, Oxford/New York.

Von Hippel, E., 2001a. Innovation by user communities: learning from open-source software. Sloan Management Review 42 (4), $82-86$.

Von Hippel, E., 2001b. User toolkits for innovation. Journal of Product Innovation Management 18, 247-257. 